\title{
A Cost-benefit Analysis of Substituting Bamboo for Tobacco: A Case Study of Smallholder Tobacco Farmers in South Nyanza, Kenya
}

\author{
${ }^{1}$ Peter Omari Magati , ${ }^{2}$ Jacob K. Kibwage, ${ }^{3}$ Seth Gor Omondi, ${ }^{3}$ George Ruigu, ${ }^{4}$ Winfred Omwansa \\ ${ }^{1}$ School of Finance and Applied Economics, Strathmore University \\ P.O. Box 59857 -00200, Nairobi, Kenya \\ Corresponding Author:Email: pmagati@strathmore.edu \\ ${ }^{2}$ School of Environment and Natural Resources Management \\ South Eastern University College (A Constituent College of University of Nairobi) \\ P.0. Box 170 - 90200, Kitui Kenya. \\ Email :jkkibwage@yahoo.com \\ ${ }^{3}$ School of Economics, University of Nairobi \\ P.O. Box 30197-00100, Nairobi, Kenya \\ Email: asegogor@yahoo.com \\ ${ }^{4}$ School of Applied Mathematics, \\ Maseno University, P.O. Box 333, Maseno, Kenya \\ Email - aomwansa@yahoo.com
}

\begin{abstract}
This study examined the economic and financial benefits and costs of farming bamboo as a crop substitute of tobacco in four (4) districts in South Nyanza, Kenya. The World Health Organization Framework Convention on Tobacco Control was developed in response to the globalization of the tobacco epidemic and Article 17 requires signatories to provide support for economically viable alternative activities to tobacco farming. Farmers, who depend on tobacco production for their livelihood, will therefore need other alternative crops to produce.

A multistage and stratified random sampling was used to select 210 tobacco farmers. One administrative location with the highest location of tobacco farmers was selected from each of the district through stratification where we used a proportional sample which was selected randomly for the study. Afterwards, a survey was carried out using a standard questionnaire with both structured and unstructured questions that was relevant for the study. Using the primary data, the study applied the framework of cost benefit analysis to analyze the cost and benefits of both tobacco and bamboo . Results of the base scenario showed that bamboo farming is financially and economically beneficial to tobacco farming since the incremental benefits are positive. A sensitivity analysis showed no change in the sign of the net incremental benefit. Results indicate the Net Present Value at the end of the project will be KShs 155,444.51 for tobacco farmers and KShs $663,272.10$ for bamboo farmers. Bamboo farming therefore, if well managed can meet the objective of alternative livelihood to tobacco farming.
\end{abstract}

Keywords: Tobacco, bamboo, cost-benefit analysis, Kenya, South Nyanza

\section{INTRODUCTION}

Tobacco is widely grown as a cash crop in many developing countries of the world where it owes its existence to wealthy multinational companies who act as growers, traders and manufacturers at the expense of the small holder farmer.In Kenya, tobacco is grown in three regions, namely, South Nyanza (Migori, Kuria and Homa-Bay districts), Western (Bungoma, Bumula, Malakisi, Sirisia, Busia, Teso and Mount Elgon districts), and Eastern (Meru, Embu and Kirinyaga districts). (see figure 1). Historically, the South Nyanza region has been the leading in tobacco producution in the country. The tobacco sector is facing a multiple of economic as well as socio-cultural and gender issues. The sector is confronted by food insecurity concerns, occupational and environmental health hazards, and environmental concerns (Kibwage et al., 2007). Some of the key economic reasons associated with tobacco production in the South Nyanza region include the fact that most farmers are attracted and trapped into tobacco production due to the belief that the crop has more and quicker cash returns than other crops (Ochola et al 2007).

Article 17 of the World Health Organization Framework Convention on Tobacco Control (WHO FCTC) requires the parties to the framework to co-operate with each other and with competent international and regional organizations to promote economically viable alternatives for tobacco growers. It also emphasizes on the need for governments to come up with nationally developed strategies for sustainable development of the affected workers and growers. Base results in South Nyanza have shown that farmers are willing to move to other viable alternatives to tobacco in Kenya (Kibwage et al 2009).

Bamboo was selected for experimentation in this study because of its economic productivity which can reach up to an annual yield of 20-40 tons per hectare on a managed plantation (Kibwage et al 2008). Due to its high potential to protect and conserve water and soil, lightweight, high elasticity and great resistance to rapture characteristics, bamboo is ideal for economic, environmental conservation, household and industrial use. It can be used in the production of pulp and paper, handicrafts, several household goods, rehabilitation and stabilization of gullies and riverbeds and recycling and filtration of domestic and industrial wastewater. Bamboo shoots are a good source of human food, while the leaves are widely used for animal fodder. (Kibwage et al 2008).

\section{MATERIALS AND METHODS}

\section{Study Area}

The project sites as shown in figure 1 for the study are Ngenge in Migori District; Ekerege in Kuria District; and Mbita, Homabay, Rangwe in Homa bay District and Sindo in Suba District. All these sites are in South Nyanza, Kenya. Sampling Design and Data Collection A multistage and stratified random sampling was used to select 210 tobacco households from the districts. One administrative location 
with the highest location of tobacco farmers was selected from each of the district through stratification where we used a proportional sample which was selected randomly for the study. Afterwards, a survey was carried out using a standard questionnaire with both structured and unstructured questions that was relevant for the study.

The project team in the research in collaboration with the Ministry of Agriculture identified 120 experimental bamboo sites (farms) i.e. 30 farms/farmers in each district. The criteria used in the selection of farmers included: whether one is a tobacco farmer or not, sex, age, poverty status, farming scale, access to water and the willingness to provide land for bamboo experimentation/ farming. Key informants were also interviewed in several tobacco collection centers and major processing areas. Secondary data was gathered from relevant literature sources. Data Analysis and Model Specification Descriptive statistics was used with the aid of excel computer package and SPSS. The costs and benefits for the years 2006-2007 and 2009-2016 were extrapolated using the data from bamboo farming for 2006. The data for tobacco for 2007 was used to estimate the costs and benefits for tobacco from 2007-2016.

The study applied two empirical models for CBA; financial analysis and economic analysis. No inflation has been assumed for purposes of appraisal. The assumption is that it affects all costs and benefits in the same way and therefore will not affect the relative returns (Campbell and Brown, 2003). Nominal rate of interest is used as a discounting rate assuming that prices of all commodities inflate in the same rate and no risk is included in the discounting rate. Below is the model being to $\mathrm{b}$ e estimated;

$$
\mathrm{NPV}=\sum_{t=0}^{T}\left(\frac{N B_{t}}{(1+r)^{t}}\right) \frac{\dot{j}}{j}
$$

Where:

$\mathrm{NB}=$ Net Benefit $=$ Gross Income - Costs

$\mathrm{T}=$ Time

$\mathrm{R}=$ Rate of interest

The following are the variables of the model being estimated;

\section{Revenue:}

Revenue which is measured by the Gross Income (GI) is the total value of output produced. GI will be computed by multiplying average yield by average price at farm level. GI includes output produced during the year, which may be sold, used for household consumption, used on the farm for seed, used for payments in kind; or kept in the store for future sale (ending stock). Non market transactions are valued at their opportunity cost (average market price).

\section{Costs:}

Costs are measured by;

a) Operating costs: These refer to the sum of input costs, traction contract costs and hired labour costs. Input costs consists of value of expenses incurred on seeds, fertilizers, insecticides, fungicides and herbicides while traction costs consists of opportunity costs for using tractors or oxen for primary land tillage. Non-purchased seeds are valued at their opportunity costs i.e. market price.

b) Opportunity cost of operating capital: This is estimated at $14 \%$ of cash/operating cost. $14 \%$ was chosen because it is based on average bank lending rate for 2006 (CBK 2006). c) Opportunity cost of family labour: This is the value of family labour used, which is valued at local wage rate (this study has used the average of the cost paid for hired labour by operation).

d) Total Enterprise Costs (TEC): This refers to values of all inputs used in production. It is the sum of operating costs, opportunity cost of equity capital, and opportunity cost of family labour. Total costs are generally divided into total variable costs and total fixed costs. In this study, fixed costs will be excluded. The study will focus on evaluating the farm's profitability on a short term basis because in the short run, a firm's output level is determined by variable factor inputs. Since in the short term fixed costs are ignored, net returns is defined as gross income per unit of activity, and expressed in Kenya Shillings per acre.

\section{Bamboo Harvest Estimation:}

The data used in the estimation was collected at intervals of 3 and 6 months. During the intervals shoots that were not counted must have sprung up to culms. Thus the best way to get the number of shoots is by getting the difference in number of culms between consecutive periods.

\section{Model assumptions:}

1. We assume shooting is continuous and uniform and that the shooting rate will be the same over each year since we wish to maintain the same number of culms per clump. Thus we harvest the mature culms equivalent to the number of shoots springing up.

2. We further assume that a culm that is 2 years old is ready for harvesting especially for weaving purposes.

3. We assume that harvesting occurs for oldest culms in a clump before new ones are harvested.

4. Another assumption is that shoots come one after another at equal time intervals over the year.

5. Similarly harvesting is done at equal time intervals culm by culm over the year. Let the mean shooting rate be $\lambda$ (shoots per year) and the mean culm harvest rate be $\mu$ (culms per year) shooting is a poison process while harvesting is exponential with the stated means respectively. To maintain a particular density of forest, the number of culms harvested should be proportional to the shooting rate.

The whole process is a queuing type. The problem is to determine the harvest rate given the shooting rate with time. The expected waiting time in the queue (between shooting and harvesting)Wq is given by the equation:

$$
W_{q}=\frac{\lambda}{\mu(\mu-\lambda)}
$$


Suppose a shoot waits for 24 months to be harvested. Then if the number of shoots springing up per year is 12 (as is determined from the data), that is 1 per month then average the number of culms to be harvested per month is:

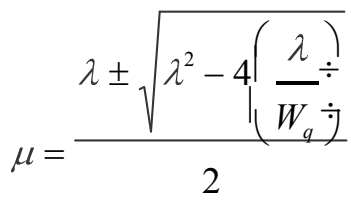

This gives the mean rate of harvesting as 11.477 culms per clump per year. For a farm with 200 clumps, the expected harvest per year is 2295 culms per annum.

At any given time, the number of culms (including new shoots) waiting for harvesting is:

$$
L_{q}=\frac{\mu}{(\mu \bar{t} \lambda)}
$$

Note that the production rate must be higher than the harvest rate to ensure continuity of the forest.

This for our example is has been computed and found to be 22 plants. This means that over $60 \%$ (66\% in particular) of the forest is maintained.

The model equations for estimating the average number of culms per clump for Giant species are as follows.

$Y($ giant $)=-0.0002 x^{3}+0.0175 x^{2}+0.3119 x+0.603$ with $R^{2}=0.9934$ (4)

$\mathrm{Y}$ is the estimated average yield per culm with period $(\mathrm{x})$ in months.

This are good fits since the coefficient of determination is greater than 0.99 meaning that over $99 \%$ of the number of culms per clump is determined by the period since planting.

\section{RESULTS}

\section{Financial Cost-Benefit Analysis - Tobacco}

Table 1 shows that on average farmers use a total of 227 man days per acre per crop. The results indicate that a large share of total labour is used for weeding (39.6\%), followed by planting $(20.0 \%)$ and tending of the crop in the nursery (7.0\%). Family labour also constitutes about $74 \%$ of total labour used in tobacco production.

Table 2 shows the other costs that would be incurred in planting tobacco per acre. It shows that an additional cost of KShs 15,674 would be used in the cultivation of tobacco.

\section{Direct Benefits to the Farmer - Tobacco}

The average gross income of a farmer per acre has been estimated at KShs 58,452. Total enterprise cost (TEC) average KShs $35,083.80$. The operating costs excluding the opportunity cost of operating capital and family labour average KShs 21,343.80. This study calculated the average gross income per acre and the TEC and used it as a basis of comparison with the Cost Benefit Analysis of bamboo.

\section{Financial Cost Benefit Analysis - Giant Bamboo}

Table 3 shows that on average farmers use a total of 179 man days per acre per crop season. It is also clear that unlike tobacco, the family would not have to use hired labour in bamboo cultivation. Converting the labour hours into monetary terms would show that the total cost in bamboo cultivation in a crop season is KShs 26,835 .

The cost of seedlings is a onetime cost and is estimated at KShs 30,000 as shown in table 4 .

\section{Direct Benefits to the Farmer - Bamboo}

The price per culm in the study area in the year 2006 was KShs 80 (UNIDO, 2006). This means that ceteris paribus, the annual revenue per acre will be KShs 183,600. Since the farmers can only start harvesting bamboo two years after planting the farmers would therefore need to get an alternative in the two years before harvesting. This study therefore proposed that another crop can be planted in the two years while bamboo grows. This is because bamboo can be intercropped with other crops. The study recommended either kales which have a net income per acre of KShs $48,000.00$ (Ochola et al 2007) or beans which have a net income per acre of KShs 20,000.00. The two have been tested in this area and found to be successful.

\section{Simulation Results}

Cost Benefit Analysis requires a stream of costs and benefits so as to calculate incremental net benefits. This involved projecting future flows of costs and benefits, discounting them and then applying a decision criterion to decide whether a project is worthwhile. Based on Ochola et al 2007, it was possible to collect data for the year 2006 for tobacco and for kales for the same year (Ochola et al 2007). This aided our assumption that farmers covered by this study were estimated to start harvesting in the year 2010. This necessitated projection so as to get the data from 2006 to 2016, the period covered by this study. The best method would have been regression analysis with the yield as the dependent variable and the independent variables would include among others; the determinants of yield- rainfall, temperature, soil fertility, farmers age and experience. In this case, the coefficients for the year 2006 would have been used to project various costs and benefits for the period covered by the study. However, due to data limitation this was not possible. The regression could not be run without varying independent variables such as rainfall and temperature. Data on some independent variables were only available for one year, 2006, making projection using regression analysis for 2006 impossible for other years. Consequently, simulation was done using population growth rate for the region at $3.0 \%$.

The financial CBA at $14 \%$ (average bank lending rate in $2006)$ indicate that the net present value is positive when excluding national costs and benefits. Table 5 and 6 indicates the Net Present Value (NPV) at the end of the project will be KShs 155,444.51 for tobacco farmers and KShs $663,272.10$ for bamboo farmers.

To get the financial incremental benefit, the net benefit for not farming tobacco is deducted from the net benefits from farming bamboo. As indicated in Table 7, the results pointed to a positive incremental net benefit at $14 \%$ discount rate; that is, the average local bank lending rate in 2006. Following the analysis, farming bamboo is found to be financially profitable since there is a net incremental benefit of KShs 507,828. 


\section{Results of Sensitivity Analysis}

A sensitivity analysis is a tool that measures the responsiveness of a margin to changes in one or more of the elements comprising that margin. It is a highly flexible device, and can be used in relation to any financial measure, including gross margins, profit, cash flow, bank balance, net capital, and rate of return on capital. The sensitivity analysis of the financial model was run by changing the discount rates while holding the time horizon at 10 years. The discount rates were adjusted upwards and downwards by $50 \%$ of the base value. The results are shown in table 8 . The table shows that the change in interest rate for financial analysis does not change the status of the NPV; they are all positive. This implies that the models are stable to changes in discount rate. The financial NPV is positive indicating bamboo farming should be initiated.

\section{DISCUSSION}

This study assumed two cases; the case involving growing of tobacco and the case of growing bamboo. A decision maker (the farmer) in this case has two alternatives; to plant tobacco or to plant bamboo. Figure 2 illustrates a decision tree where the decision maker is thought of as standing at a node.

The with-and-without approach is at the heart of costbenefit analysis and also underlies the important concept of opportunity cost. Ceteris paribus, where planting of bamboo is practiced, the benefits (especially financial) accruing to the farmers may not be the same as when the farmer is involved in planting of tobacco. These farmers will also experience an opportunity cost that is, the farming benefits of tobacco. Since tobacco is a labour intensive crop, some of the factors of its production like labour and capital which would have otherwise been employed in the production cycle, would be idle. The decision maker's objective is to make a decision using the decision rule such that if the net benefits (benefits less costs) of bamboo production exceed that of tobacco, then bamboo production should be more worthwhile.

Ochola et al 2007 carried out research on tobacco farming in south Nyanza, Kenya and found out that Tobacco exhibited the lowest return per acre in the study area when compared with commercial crops including passion fruits, soya beans, pineapple and pepper in one production cycle. In addition, it was discovered that farmers are willing to shift from tobacco and would do so if the introduced crop has an assured market, the farmers have access to credit to purchase farm inputs, and technical support among others. Farmers indicated that they would adopt commercial crops which they would also use for home consumption. The research also found out institutions promoting production of alternative crops in the study area faced capacity and resource constraints which impacted negatively on their operations. The study also revealed that those farmers who shifted to other crops exhibited higher standards of living compared to those who continued to grow tobacco.

Naher et al, 2007 observed the situation of tobacco growing and vegetable areas. Research for this case study involved travel to key tobacco growing regions of Bangladesh as well as collection of information in Dhaka from various sources. During the fieldwork, researchers observed the situation of tobacco growing and vegetable growing areas, and spoke to current and former tobacco farmers about their economic situation and their reasons for growing tobacco or switching from tobacco to other crops. It emerged that the principal reason behind farmers choosing to grow tobacco is that it is considered to be more profitable than other crops due to its guaranteed market and that the farmer receives his entire money for his produce at once. The study also observed that the key benefits of tobacco growing, meanwhile, accrue mainly to registered farmers only, while unregistered farmers often receive a lower price for their tobacco leaf, depending on registered farmers to buy whatever quantity they may need.

Krishnankutty (2004) carried out a cost-benefit analysis of bamboo in comparison with other crops in mixed home gardens in Kerala State, India. A statistically designed survey was carried out in home gardens in two different agroclimatic zones in Kerala to analyse profitability of bamboo in comparison with seasonal-annual crops, perennial crops and tree crops. Benefit-cost analysis shows that bamboo has at least a second position in terms of profitability among the crop groups in home gardens in the two zones. The high benefit-cost ratio of bamboo was due to negligible inputs and high farm price of bamboo. Advantages due to the existence of an organized wholesale market near the study area and the efficiency of the bamboo depots there make bamboo growing in home gardens profitable.

It is clear that tobacco is not as beneficial as is commonly perceived.Krishnankutty (2004) indicated that tobacco farmers' cost of living compared to other farmers within the same locality is not better. It is also evident that there are economic and environmental benefits that communities derive from bamboo production. Economic benefits can easily be monetized unlike environmental costs but can be given monetary values using indirect methods like contigent valuations and benefit transfers. These benefits and costs can be discounted so as to get their present values.

Results of the base scenario of this study showed that bamboo farming is financially and economically beneficial to tobacco farmers since the incremental benefits are positive. This is shown by the results which indicate that whilst the financial net present value for tobacco farmers is KShs 155,445 that of bamboo farmers is KShs 663,272. It is also evident that bamboo farming takes on average 179 days of labour per season as opposed to the 227 man days for tobacco farming. Holding other factors constant, this leaves the community with 48 more days to diversify to other income generating activities.

The results also indicate that the Total Enterprise Cost (TEC) of farming bamboo is higher at KShs 56,835 compared to KShs 35,084 for tobacco. This is however offset by the fact that the gross average income for bamboo is KShs 183,600 and that of tobacco is KShs 58,452 . Bamboo farming therefore, if well managed can meet the objective of the Framework Convention on Tobacco Control and also the government as it seeks to find an alternative to tobacco growing. 
The study concludes that bamboo is economically and financially viable as an alternative to tobacco farming if well managed. If the government and the people in South Nyanza are committed towards bamboo cultivation, then environmental restoration can also be enhanced. It will also allow for farmers to increase food production in the area since bamboo is amenable to intercropping in the first two years and restores degraded areas as is the case in tobacco growing areas. The government should contribute towards encouraging farmers to grow bamboo and provide incentives to the farmers for growing the crop. The incentives may be in the form of cash advance and supply of inputs such as seedlings.

\section{ABBREVIATIONS}

WHO FCTC - World Health Organization Framework Convention on Tobacco Control

NPV - Net Present Value

CBA - Cost Benefit Analysis Kshs - Kenya Shillings where One United States Dollar (1 USD) = 80 Kshs

\section{ACKNOWLEDGEMENTS}

We wish to acknowledge the assistance given by the International Development Research Center (IDRC), Ottawa, Canada through their grant which enabled us carry this study. Maseno University and South Eastern University College are also acknowledged for their institutional and implementation support. The study by Dr. Samuel Ochola and Prof Willis Kosura that looked at a Tobacco Cultivation and Possible Alternative Crops in Kenya formed an important part of this study. Finally, all stakeholders and participants who contributed to this work are acknowledged.

\section{REFERENCES}

1. Campbell, H.F. and Brown R.P.C., (2003). Benefit-Cost Analysis: Financial and Economic Appraisal using Spreadsheets. Cambridge University Press, Cambridge

2. Kibwage JK, Momanyi GM, Odondo AJ (2007). Occupational Health and Safety Concerns of smallholder tobacco farmers. African Newsletter on Occupational Health and Safety, Finish institute of Occupational Health, Finland. 17(2).
3. Kibwage JK, Netondo GW, Odondo AJ, Oindo BO, Momanyi GM, Jinhe $\mathrm{F}$ (2008). Growth performance of bamboo in tobacco-growing regions in South Nyanza, Kenya. Afr. J. Agric. Res. 3 (19): 716-724.

4. Kibwage JK, Odondo AJ, Momanyi GM, (2009). Assessment of livelihood assets and strategies among tobacco and non-tobacco growing households in South Nyanza, Kenya. Afr. J. Agric. Vol 4 (4): 294-304.

5. Krishnankutty, C.N., (2004)., Benefit-Cost Analysis of Bamboo in Comparison with Other Mixed Crops in Mixed Cropping Home Gardens in Kerala State, India. Journal for Bamboo and Rattan, 3(2): 99-106.

6. Naher, F. and Efroymson, D., (2007)., Tobacco Cultivation and Poverty in Bangladesh, Study conducted as a technical document for the first meeting of the Ad Hoc Study Group on Alternative crops established by the Conference of the Parties to the WHO Frame work Convention on Tobacco Control (February,2007).

7. Ochola S. , Kosura W., (2006) Case Study on Tobacco Cultivation and Possible Alternative Crops-Kenya, Study conducted as a technical document for the first meeting of the Ad Hoc Study Group on Alternative crops established by the Conference of the Parties to the WHO Frame work Convention on Tobacco Control (February,2007).

8. Republic of Kenya., (1989). South Nyanza Development Plan 19891993. Government Printer, Nairobi.

-., (2002a)., Kuria District Development Plan 20022004.Government Printer, Nairobi.

-., (2002b)., Migori District Development Plan 2002-2004.Government Printer, Nairobi.

- ., (2002c)., Homa Bay District Development Plan 2002-2004. Government Printer, Nairobi.

-., (2002d)., Suba District Development Plan 2002-2004.Government Printer, Nairobi.

-., (2007)., Statistical Abstract., Kenya National Bureau of Statistics, Nairobi: Government Printer, Nairobi.

-., (2008)., Statistical Abstract., Kenya National Bureau of Statistics, Nairobi: Government Printer, Nairobi.

-., (2009)., Statistical Abstract., Kenya National Bureau of Statistics, Nairobi: Government Printer, Nairobi.

9. UNIDO, (United Nations Industrial Development Organization) 2006. . Technical Report: Bamboo Plantations for the Eastern Africa Bamboo Project, Kenya, With a Feasibility Study For a 100 Ha Plantation, 2006. United Nations: Austria. 


\section{TABLES}

Table 1: Financial Costs of Farming Tobacco (Labour costs - average man days per acre) ${ }^{1}$

\begin{tabular}{|l|l|l|l|l|}
\hline Operation and Labour Type & Labour Type & No. of Days & Cost per unit (KShs) & $\begin{array}{l}\text { Total } \\
\text { (Kshs/acre) }\end{array}$ \\
\hline Nursery Management & Family & 15 & 150 & $2,250.00$ \\
\hline Land Preparation & Family & 9 & 150 & $1,350.00$ \\
\hline Ridging & Family & 3 & 150 & 450.00 \\
\hline Planting & Family & 16 & 60 & 960.00 \\
\hline & Hired & 20 & 60 & $1,200.00$ \\
\hline Weeding & Family & 73 & 60 & $4,380.00$ \\
\hline & Hired & 17 & 60 & $1,020.00$ \\
\hline Applying fertilizer & Family & 5 & 60 & 300.00 \\
\hline Applying Agrohemicals & Family & 2 & 60 & 120.00 \\
\hline Manual desuckering & Family & 1 & 60 & 60.00 \\
\hline & Hired & 1 & 300 & 300.00 \\
\hline Manual pest control & Family & 10 & 60 & 600.00 \\
\hline Harvesting & Family & 4 & 130 & 130.00 \\
\hline & Hired & 9 & 130 & $1,170.00$ \\
\hline (Tying on curing sticks) & Hired & 10 & 180 & $1,800.00$ \\
\hline Transporting to the barn & Family & 2 & 60 & 120.00 \\
\hline Transporting to the barn & Hired & 3 & 60 & 180.00 \\
\hline Curing & Family & 10 & 200 & $2,000.00$ \\
\hline Sorting/Grading & Family & 12 & 60 & 720.00 \\
\hline Balling & Family & 2 & 60 & 120.00 \\
\hline Packing & Family & 3 & 60 & 180.00 \\
\hline Total & Family & $\mathbf{1 6 7}$ & & $\mathbf{1 3 , 7 4 0 . 0 0}$ \\
\hline & Hired & $\mathbf{6 0}$ & $\mathbf{5 , 6 7 0 . 0 0}$ \\
\hline & Total & $\mathbf{2 2 7}$ & $\mathbf{1 9 , 4 1 0 . 0 0}$ \\
\hline & & & \\
\hline
\end{tabular}

Table 2: Average Quantity and Cost of Input Use per Acre ${ }^{2}$

\begin{tabular}{|l|l|l|l|l|}
\hline Item & Type & Units & Unit price & Total cost \\
\hline Fertilizer & NPK & 3 KG & $1,895.00$ & $5,685.00$ \\
\hline Agro chemicals & Confidor & 350MLS & $2,250.00$ & $2,250.00$ \\
\hline & Pygro & 300MLS & 900.00 & 900.00 \\
\hline & Off shoot - T & 5 LITRES & $2,000.00$ & $2,000.00$ \\
\hline & Copper & - & 75.00 & 75.00 \\
\hline Curing pipes & 1 & N.A & N.A & 138.80 \\
\hline Sprayer & 1 & N.A & N.A & 625.00 \\
\hline Curing wood & 1 & N.A & N.A & $4,000.00$ \\
\hline Total & & & & $\mathbf{1 5 , 6 7 3 . 8 0}$ \\
\hline Source & & &
\end{tabular}

Source - Field Survey.

\footnotetext{
${ }^{1}$ The data was obtained from Ochola et al 2007

${ }^{2}$ The data was obtained from Ochola et al 2007

How to Cite this Article: Peter Omari Magati ,Jacob K. Kibwage, Seth Gor Omondi, George Ruigu, Winfred Omwansa, "A Cost-benefit Analysis of Substituting Bamboo for Tobacco: A Case Study of Smallholder Tobacco Farmers in South Nyanza, Kenya" Science Journal of Agricultural Res earch \& Management, Volume 2012, Article ID sjarm-204, 9 Pages, 2012.
} doi: $10.7237 /$ sjarm/204 
Table 3: Financial Costs of Farming Giant Bamboo (Labour Costs - average man days per acre)

\begin{tabular}{|l|l|l|l|l|}
\hline Operation and Labour Type & Labour Type & No. of Days & Cost per unit (KShs) & Total Cost (Kshs/acre) \\
\hline Nursery Management & Family & 5 & 150 & 750.00 \\
\hline Land Preparation & Family & 30 & 150 & $4,500.00$ \\
\hline Ridging & Family & 4 & 150 & 600.00 \\
\hline Planting & Family & 10 & 150 & $1,500.00$ \\
\hline Weeding & Family & 48 & 150 & $7,200.00$ \\
\hline Applying fertilizer & Family & 4 & 150 & 600.00 \\
\hline Applying Agrochemicals & Family & 4 & 150 & 600.00 \\
\hline Manual desuckering & Family & 4 & 150 & 600.00 \\
\hline Prunning & Family & 24 & 150 & $3,600.00$ \\
\hline Harvesting & Family & 45.9 & 150 & $6,885.00$ \\
\hline Total & & $\mathbf{1 7 8 . 9}$ & $\mathbf{1 5 0}$ & $\mathbf{2 6 , 8 3 5 . 0 0}$ \\
\hline
\end{tabular}

Table 4 shows the cost of 200 seedlings in a one acre piece of land.

\begin{tabular}{|l|l|l|l|l|}
\hline Item & Type & Units & Unit price & Total cost \\
\hline Seedlings & One time cost & 200 & 150 & $\mathbf{3 0 , 0 0 0 . 0 0}$ \\
\hline
\end{tabular}

Table 5: Financial Net Present Values for Tobacco Farmers

\begin{tabular}{|l|l|l|l|l|}
\hline & & & & \\
Year & Benefits & Costs & Net Benefits & NPV (14\%) \\
\hline 2006 & $58,452.00$ & $35,083.80$ & $23,368.20$ & $12,136.71$ \\
\hline 2007 & $60,205.56$ & $36,136.31$ & $24,069.25$ & $12,500.81$ \\
\hline 2008 & $62,011.73$ & $37,220.40$ & $24,791.32$ & $12,875.84$ \\
\hline 2009 & $63,872.08$ & $38,337.02$ & $25,535.06$ & $13,262.11$ \\
\hline 2010 & $65,788.24$ & $39,487.13$ & $26,301.11$ & $13,659.97$ \\
\hline 2011 & $67,761.89$ & $40,671.74$ & $27,090.15$ & $14,069.77$ \\
\hline 2012 & $69,794.74$ & $41,891.89$ & $27,902.85$ & $14,491.87$ \\
\hline 2013 & $71,888.59$ & $43,148.65$ & $28,739.94$ & $14,926.62$ \\
\hline 2014 & $74,045.24$ & $44,443.11$ & $29,602.14$ & $15,374.42$ \\
\hline 2015 & $76,266.60$ & $45,776.40$ & $30,490.20$ & $15,835.65$ \\
\hline 2016 & $78,554.60$ & $47,149.69$ & $31,404.91$ & $16,310.72$ \\
\hline & & & TOTAL & $155,444.51$ \\
\hline
\end{tabular}

Table 6: Financial Net Present Values for Bamboo Farmers

\begin{tabular}{|l|l|l|l|l|}
\hline Year & Benefits & Costs & Net Benefits & NPV (14\%) \\
\hline 2006 & - & - & $48,000.00$ & $24,929.70$ \\
\hline 2007 & - & - & $49,920.00$ & $25,926.88$ \\
\hline 2008 & - & - & $51,916.80$ & $26,963.96$ \\
\hline 2009 & $56,835.00$ & $183,600.00$ & $126,765.00$ & $65,837.77$ \\
\hline 2010 & $58,540.05$ & $189,108.00$ & $130,567.95$ & $67,812.90$ \\
\hline 2011 & $60,296.25$ & $194,781.24$ & $134,484.99$ & $69,847.29$ \\
\hline 2012 & $62,105.14$ & $200,624.68$ & $138,519.54$ & $71,942.71$ \\
\hline 2013 & $63,968.29$ & $206,643.42$ & $142,675.12$ & $74,100.99$ \\
\hline 2014 & $65,887.34$ & $212,842.72$ & $146,955.38$ & $76,324.02$ \\
\hline 2015 & $67,863.96$ & $219,228.00$ & $151,364.04$ & $78,613.74$ \\
\hline 2016 & $69,899.88$ & $225,804.84$ & $155,904.96$ & $80,972.15$ \\
\hline & & & & $663,272.10$ \\
\hline
\end{tabular}


Table 7: Financial Incremental Net Benefits

\begin{tabular}{|c|c|c|c|}
\hline & & & \\
Net Benefits Bamboo & Net Benefits Tobacco & Net incremental benefits & $\begin{array}{l}\text { Net Incremental benefit } \\
\text { (14\%) }\end{array}$ \\
\hline $48,000.00$ & $23,368.20$ & $24,631.80$ & $12,792.99$ \\
\hline $49,920.00$ & $24,069.25$ & $25,850.75$ & $13,426.07$ \\
\hline $51,916.80$ & $24,791.32$ & $27,125.48$ & $14,088.12$ \\
\hline $126,765.00$ & $25,535.06$ & $101,229.94$ & $52,575.66$ \\
\hline $130,567.95$ & $26,301.11$ & $104,266.84$ & $54,152.93$ \\
\hline $134,484.99$ & $27,090.15$ & $107,394.84$ & $55,777.51$ \\
\hline $138,519.54$ & $27,902.85$ & $110,616.69$ & $57,450.84$ \\
\hline $142,675.12$ & $28,739.94$ & $113,935.19$ & $59,174.37$ \\
\hline $146,955.38$ & $29,602.14$ & $117,353.24$ & $60,949.60$ \\
\hline $151,364.04$ & $30,490.20$ & $120,873.84$ & $62,778.08$ \\
\hline $155,904.96$ & $31,404.91$ & $124,500.05$ & $64,661.43$ \\
\hline $1,277,073.78$ & $299,295.13$ & $977,778.65$ & $507,827.59$ \\
\hline
\end{tabular}

Table8: Change of Discount Rate Effect on Net Present Value of Financial Values

\begin{tabular}{|l|l|}
\hline & \\
Parameters & Financial Incremental net benefit at 14\% \\
\hline NPV at $7 \%$ & $697,142.66$ \\
\hline NPV at base value (14)\% & $507,827.59$ \\
\hline NPV at $21 \%$ & $376,976.00$ \\
\hline
\end{tabular}

\section{FIGURES}

Figure 1: Study Area Sites in South Nyanza, Kenya

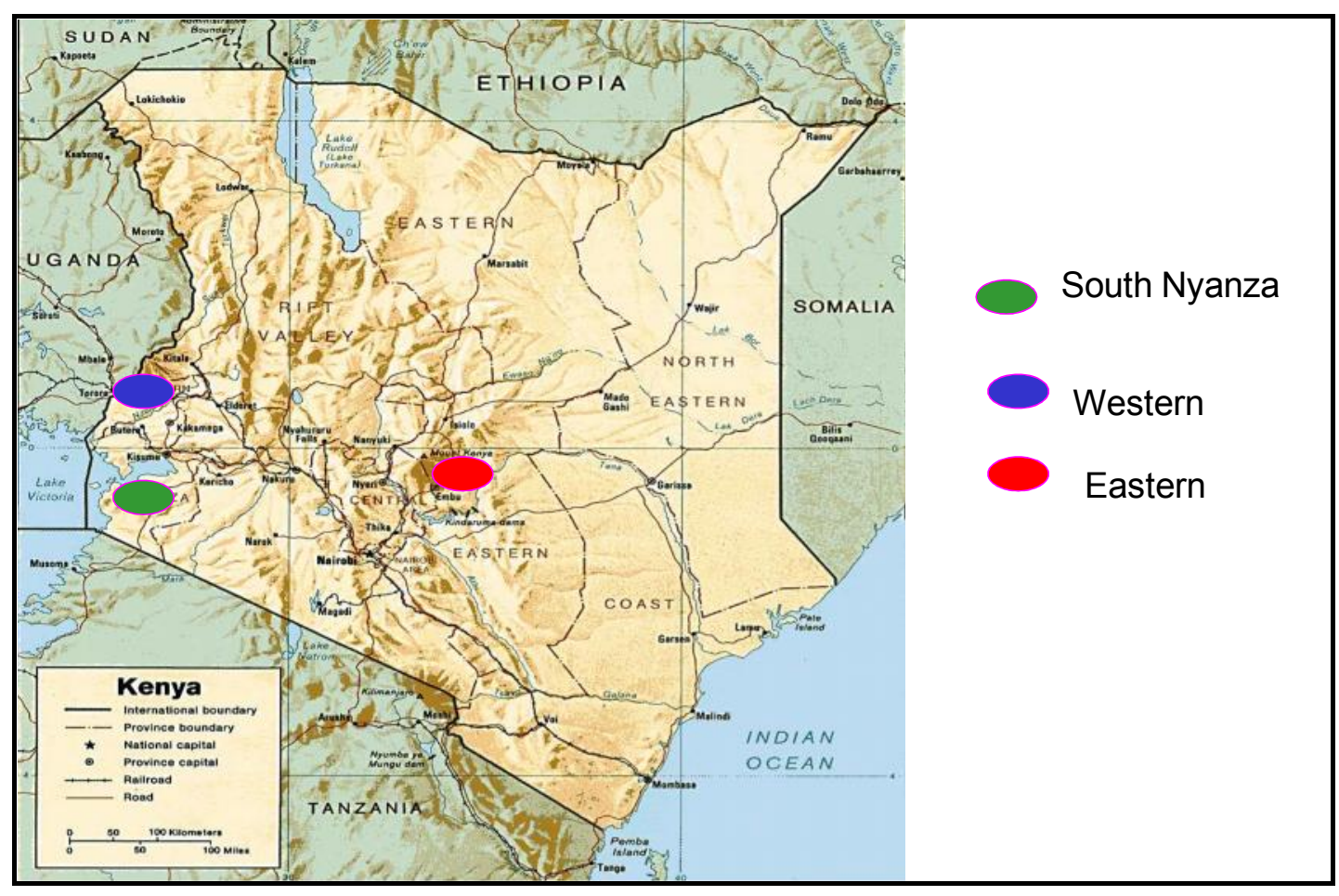

How to Cite this Article: Peter Omari Magati ,Jacob K. Kibwage, Seth Gor Omondi, George Ruigu, Winfred Omwansa, "A Cost-benefit Analysis of Substituting Bamboo for Tobacco: A Case Study of Smallholder Tobacco Farmers in South Nyanza, Kenya" Science Journal of Agricultural Res earch \& Management, Volume 2012 , Article ID sjarm-204, 9 Pages, 2012. doi: $10.7237 /$ sjarm/204 
Figure 2: Bamboo Production Decision Tree

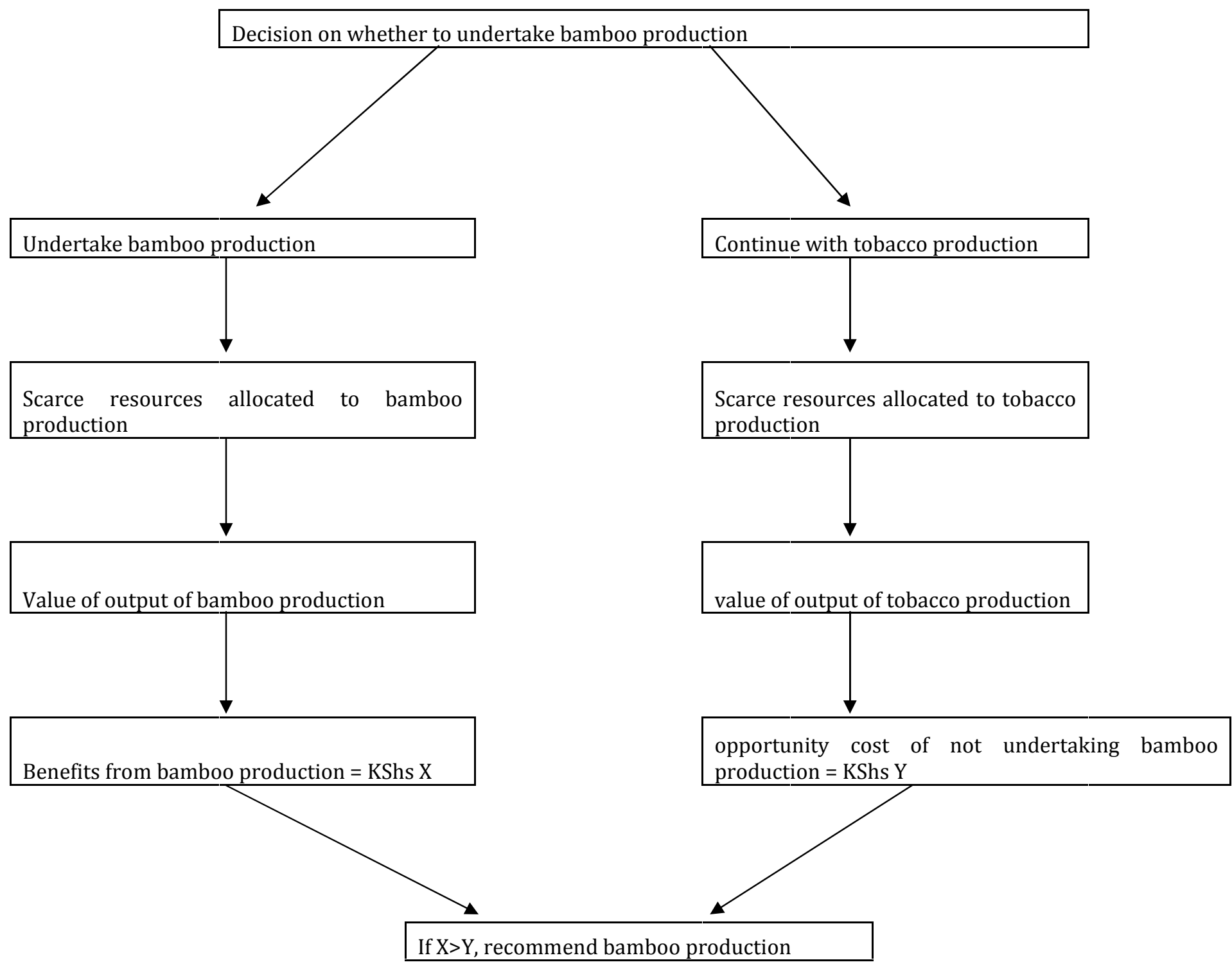

How to Cite this Article: Peter Omari Magati ,Jacob K. Kibwage, Seth Gor Omondi, George Ruigu, Winfred Omwansa, "A Cost-benefit Analysis of Substituting Bamboo for Tobacco: A Case Study of Smallholder Tobacco Farmers in South Nyanza, Kenya” Science Journal of Agricultural Research \& Manag ement, Volume 2012, Article ID sjarm-204, 9 Pages, 2012. doi: $10.7237 /$ sjarm/204 